\title{
THE RELATIONSHIP BETWEEN SYSTEMATIC SOLDIERING AND ORGANIZATIONAL COMMITMENT IN HOSPITALITY BUSINESSES ${ }^{1}$
}

\author{
Prof. Serkan BAYRAKTAROĞLU* \\ Assoc. Prof. Metin ULUKÖY ${ }^{* *}$ \\ Res. Asst. Çă̆rı İZCí $\dot{I}^{* * *}$
}

\begin{abstract}
People are inherently lazy and tend to not like working. Hence employees may end up engaging in soldiering behavior. Soldiering occurs as a result of two factors. The first factor is natural laziness which is caused by natural instincts. In this case individuals tend to ignore their jobs and responsibilities. The second factor is more systematic and complex. In this case people deliberately tend to show a slowdown their input and work less than usual. Systematic soldiering is threatening situation for organizations both from the viewpoint of individual employees and the management. As systematic soldiering is widespread almost in all organizations, most management systems attempt to increase employees' level of interest in their jobs.

The findings of this study shows that employees engage in soldiering behavior, but it is neither systematic nor significant. The results of Correlation, Anova and Factor analysis shows that there is no relationship between systematic soldiering and organizational commitment.
\end{abstract}

Key Words: Soldiering, Systematic Soldiering, Organizational Commitment

JEL Classification: M10, M12, M54

\section{TURIZM İŞLETMELERİNDE SISTEMATIKK KAYTARMA VE ÖRGÜTSEL BAĞLILIK İLişKISII}

\section{ÖZ}

İnsanlar doğası gereği tembeldir ve çalışmayı sevmez. Bu yüzden insanlar kaytarma eğilimi göstermektedirler. Kaytarma iki sebepten dolayı ortaya çıkmaktadır. Birinci sebep doğal içgüdülerden kaynaklanan doğal tembelliktir. Bu durumda insanlar işin kolayına kaçma veya aldırmama yönünde eğilimler göstermektedir. İkincisi sebep ise daha karmaşık ve sistematik olan kaytarmadır. Bu durumda insanlar, az çalışma ve kasten işi yavaşlatma eğilimleri göstermektedir. Sistematik kaytarma, hem çalışanların hem de yöneticilerin karşı karşıya bulunduğu tehlikeli bir durum olarak

\footnotetext{
${ }^{1}$ Originally published in TOURMAN 2014 "New Perspectives in Tourism Management Conference" Book of Proceedings in extended abstract form.

*Sakarya University, Faculty of Management, Department of Business Administration, serkanb@sakarya.edu.tr

** Bandırma Onyedi Eylül University, Faculty of Economics and Administrative Sciences, Department of Business Administration, mulukoy@ hotmail.com

${ }^{* * *}$ Bandırma Onyedi Eylül University, Faculty of Economics and Administrative Sciences, Department of Business Administration, cagriizci89@gmail.com
} 
görülmektedir. Sistematik kaytarma hemen hemen tüm yönetim sistemlerinde görülmekte ve çalışanların çıkarlarını arttırmak için başvurdukları tepki olarak ortaya çıkmaktadır.

Çalı̧̧mada turizm sektöründe faaliyet gösteren işletmelerde çalışanların önemsiz kaytarmalar gerçekleştirdiği sistematik kaytarmanın olmadı̆̆ı saptanmıştır. Aynı zamanda yapılan korelasyon, Anova ve Faktör analiz sonuçlarına göre Sistematik kaytarma ile örgütsel bağlllı arasında genel olarak bir ilişkinin olmadı̆̆ı saptanmıștır.

Anahtar Kelimeler: Kaytarma, Sistematik Kaytarma, Örgütsel Bağlllık

JEL Sinıflandırması: M10, M12, M54

\section{INTRODUCTION}

The literature shows that individuals are psychological beings and their level motivation influence their behavior whether be it positively or negatively (Kanten, 2014: 13). Mc Gregor puts forward that, individuals, in general, approach their jobs in two distinct and different manners. One of them is the negative view of the human beings and state that people are lazy in nature and they do not like working, and inclined to what is called soldiering. Soldiering occurs due to two factors. The first factor is the natural laziness which is caused by natural instincts. In this case individuals may tend to engage in cutting corners and neglecting. On the other hand, the second factor is more systematic and complex. According to this view people tend work less deliberately and they are prone to slowing down.

Systematic soldiering is a perilous situation both from the viewpoint of employees and employers or managers. Hence, most management systems attempt to increase employees' level of interest in their jobs (Akın, 2013: 21).

The purpose of this study is to put forth whether personnel in tourism sector is systematically soldiering, and if yes what causes are there behind their soldiering behavior and the cost of soldiering. The study also explores and analyzes the implications of systematic soldiering for the loyalty of commitment of individuals towards their organizations.

\section{SOLDIERING AND SYSTEMATIC SOLDIERING}

Soldiering means avoidance from working. Especially, people are more inclined to make less effort when they are soldiering (Kanten, 2014: 13). Why are people refraining from working or soldiering? The reason for that is people think they safeguard their interests by soldiering and going slow (Akin, 2013: 21).

Taylor, in his work 'The Principles of the Scientific Management' claims soldiering emerges due to two reasons. The first of these is the natural laziness that is caused by natural instincts. The second one is systematic soldiering that is the result of systematic thinking. The reason for this is the relation of people with others (Akın, 2013: 24). 
Systematic soldiering arises when people work in groups and is seen as an attempt of employees to hide themselves (Doğan, 2012: 56). In a similar definition, it is expressed as a decrease in employee's effort as compared to other employees performing the same job (Thompson and Thornton, 2007: 159; Ying et al, 2014: 165; Luao et al., 2013: 456; Latane et al., 1979: 823; Doğan, 2012: 57). Soldiering also occurs in the form of individual effort which is less when working in groups (Thompson and Thornton, 2007: 159; Ilgin, 2013: 241; Kanten, 2014: 13). As a result, other people working in the same group and performing a better job would decrease their performance gradually. Naturally, when an energetic employee works with a lazy one, the former would question that the latter receives the same amount despite his/her less effort. Thus, the latter would decrease his/her performance (Akın, 2013: 24).

People are lazy by nature. However, the greatest danger faced by both employees and managers is systematic soldiering. It is seen in almost all management systems as a result of workers' analysis to improve their interests (Akın, 2013: 25). In organizations, systematic soldiering can increase as a result of examination of those who are refraining from working. Therefore, it is put forth systematic soldiering declines organizational performance (Kanten, 2014: 14) by spread of soldiering (Luao et al, 2013: 456; George, 2013: 240).

A large part of the systematic soldiering is run by workers who aimed at leaving their employers uninformed about the ways in which work is done in a faster manner. Soldering done for that purpose is extremely common. (Akın, 2013: 25). In particular, social soldiering is affected by the idea of workers that their efforts would not be recognized by their managers, their attempts would be neglected and other members of the group would fill the gap. Moreover, the size of the group, the difficulty as well as the importance of the duty is influential in social soldiering behavior (Kanten, 2014: 15).

Those who are soldiering cause high costs to the businesses. In a study carried by Greenber in 2005 , it is found that a worker whose annual earning is 40.000 dollars causes 5.000 dollars loss by soldiering an hour in his/her working hours. In the same way, a research of Websense.com conducted in 2006 in America demonstrates an American worker leads a high costs by soldiering in 24\% of his/her working hours (Enver et al., 2012: 23).

\section{ORGANIZATIONAL COMMITMENT}

Manpower is the most strategic factor in increasing the efficiency and the level of development in organizations (Koc, 2010; Alavi, Mojtahedzadeh, Amin and Savoji, 2013: 815; Koc, et al., 2014). Organizations that take into account that power and turn it to advantage take the lead in the race. Those manage to survive in a competitive world are the organizations that have qualified and affiliated employees (Koc, 2003; Koc, 2009). 
As a concept and perception, commitment exists with emotional instinct as an emotional expression of this social instinct. It expresses loyalty of slave to his/her master, of civil servant to his/her job, of soldier to his homeland (Tengilimoğlu and Mansur, 2009: 71-72). Commitment stated as a psychological concept by many researchers varies from one study to another, in terms of scope and definition (Koc, 2000; Luo, Song, Marnburg and Øgaard, 2014: 22). Commitment between the two agents is not just a static event; it is a dynamic process that can change the situation at that time (Sultan, Bentahar, Wan, and Al-Saqqar, 2014: 6291).

When the issue is to maintain communication among various groups, group cohesion has become a crucial approach for more than ten years (Sultan, K., Bentahar, J., Wan, W. and Al-Saqqar, F., 2014: 6291). Group cohesion creates a suitable environment for group members to act together. It helps group members get away from pursuing their self-interest and behave in a way that in favour of group members.

Organizational survival depends on employees' continuation to work. The more commitment is held by employees, the more strong organization there is (Bayram, 2005: 125). Organizational commitment has become a vital concept for organizations due to five reasons. This concept is highly related with, first, quitting, absenteeism and job search activities, second, attitudinal, emotional, and cognitive structures such as job satisfaction, morale and performance, third, features of worker's job and role as autonomy, responsibility, participation, sense of duty, fourth, personal characteristics such as age, sex, length of service and education, and last, awareness of organizational commitment estimators (Balay, 2000: 1).

Organizational commitment is one of the widely studied areas in the organizational science literature (Ng and Feldman, 2011: 529). It has become a central topic in scientific research for long years (Morrow, 2011: 19). Organizational commitment emphasizes on staff commitment to the organizations (Bahrami et al., 2015: 2). It is one of the strongest predictors of employee success for a better performance. At the same time, it can increase creativity in organizations (Mahdi, Mohd and Almsafir, 2014: 1077).

Organizational commitment is an important concept in terms of employee productivity and intention of leave. Organizational commitment is described by Mowday et al. (1979) as the "relative strength of an individual's identification with and involvement in a particular organization." (Jung and Yoon, 2016: 61). In general, this concept expresses worker's psychological commitment to the organization with participation in work, loyalty and belief in organizational values (Tengilimoğlu and Mansur, 2009: 72). Organizational commitment includes normative pressures made for employees to work for organizational purposes, psychological interest towards the organization and the psychological expressions pushing the individual to stay in the organization (Akbolat, Işı1k and Karadağ, 2010: 44). Organizational commitment also is defined as organizational targets and the 
power of individual's identity (Permarupan, Saufi, Kasim and Balakrishnan, 2013: 92). According to another definition, organizational commitment is correlated with employee acceptance of organizational targets and his/her loyalty to the organization (Yeh, 2014: 94). Meyer and Allen (1991) states as a multi-dimensional term, organizational affiliation is the implementation of decisions related to quitting the job or continuing to work. According to Meyer and Allen (1991), it encompasses three components: Affective commitment, continuance commitment and normative commitment. Affective commitment means more than passive obedience of workers to organizational purposes and leads an active bond by persuading worker to improve organization's current position (Gürbüz, 2006: 59). In other words, emotional commitment means worker affiliation to the organization by heart, worker identification with the organization, adoption of organizational purposes wholeheartedly and being proud of the organization (Öğ̈t and Kaplan, 2011: 192). Continuance commitment, on the other hand, cares about the cost of employee leave and is defined as continuation of work as a result of necessity. Otherwise, it would have negative impacts on the organization (Boylu, 2007: 58). This commitment type can also be stated as a worker motivation due to the necessity of remaining in the organization (Casper, Harris, Taylor-Bianco and Wayne, 2011: 643). Normative commitment contains beliefs that are internalized by the individual and are consistent with organizational policies (Durna and Eren, 2005: 211). It refers to remaining in the organization because of the individual feeling that there are rules are the organizations to be obeyed (Shagholi, Zabihi, Atefi and Moayedi, 2011: 247). An individual who has high normative commitment feels that it is compulsory to stay at that position due to legal regulations (Stan, 2013: 673)

\section{RESEARCH APPLICATION}

\subsection{Methodology}

In this study that examines the relation between systematic soldiering and organizational commitment, survey technique was used for data collection. For that purpose, literature review was done and a survey questions were prepared accordingly. With convenience sampling, the survey was conducted with business employees in the tourism sector. There were 101 employees that fit into the definition. Face to face interviews were made with those people. Analysis was made by using SPSS 20.0 program. As a result of the analysis, the reliability of the scale (Cronbach's Alpha) was found as, 734.

\subsection{Results}

As a result of the analysis, under the lights of questions in the survey, data of employees in the tourism sector was prepared. This data is shown in the tables below. 
Table 1: Demographic Characteristics of Participants

\begin{tabular}{lll|lll}
\hline Education & Frequency & $\mathbf{\%}$ & Age & Frequency & \% \\
\hline Secondary School & 14 & 13,9 & $<25$ & 61 & 60,4 \\
High School & 63 & 62,4 & $26-30$ & 26 & 25,7 \\
Undergraduate & 18 & 17,8 & $31-35$ & 6 & 5,9 \\
Graduate & 6 & 5,9 & $36-40$ & 6 & 5,9 \\
& & & 41 & 2 & 2,0 \\
Total & 101 & 100,0 & Total & 105 & 100,0 \\
\hline Marital Status & Frequency & $\mathbf{\%}$ & Gender & Frequency & $\mathbf{\%}$ \\
\hline Single & 82 & 81,2 & Male & 58 & 57,4 \\
Married & 19 & 18,8 & Female & 43 & 42,6 \\
Total & 101 & 100,0 & Total & 101 & 100,0 \\
\hline
\end{tabular}

When looked at demographic characteristics of participants, it is seen $\% 13.9$ of them are secondary school graduates. While \%62.4 of the participants finish high school, this percentage becomes 17.8 and 5.9 for undergraduate and graduate levels, respectively. Those who are below 40 are $98 \%$ of the participants. $81.2 \%$ of the participants are single and $57.4 \%$ of them are male.

Table 2: Demographic Characteristics of Participants

\begin{tabular}{lll|lll}
\hline Earning & Frequency & $\mathbf{\%}$ & Position & Frequency & $\%$ \\
\hline$<1000 \mathrm{TL}$ & 85 & 13,9 & Director & 5 & 5,0 \\
$1001-1500$ & 10 & 62,4 & Chief & 16 & 15,8 \\
$1501-2000$ & 5 & 17,8 & Employee(Permanent) & 76 & 75,2 \\
$2001-3000$ & 1 & 5,9 & Employee (Seasonal) & 4 & 4,0 \\
Total & 101 & 100,0 & Total & 101 & 100,0 \\
\hline Working Hours & Frequency & $\mathbf{\%}$ & Hotel Type & Frequency & $\mathbf{\%}$ \\
\hline 08:00-17:00 & 87 & 86,1 & Front Office & 21 & 20,8 \\
17:00-24:00 & 8 & 7,9 & Food Services & 55 & 54,5 \\
24:00-08:00 & 6 & 5,9 & Accommodation Ser. & 19 & 18,8 \\
& & & Entertainment Ser. & 3 & 3,0 \\
& & & Administrative Ser. & 3 & 3,0 \\
Total & 101 & 100,0 & Total & 101 & 100,0 \\
\hline
\end{tabular}

According to demographic characteristics of those answering the questionnaire, $13.9 \%$ of them earn less than 1000 TL. For the intervals 1001-1500, 1501-2000 and 2001-3000, the percentages become $62.4,17.8$ and 5.9, respectively. $75.5 \%$ of the participants are permanent workers and $4 \%$ of them have seasonal job. $86.1 \%$ of them work between 08.00 and $17.00,7.9 \%$ do the same between 17.00 and 24.00 . In addition, $5.9 \%$ of the participants work between 24.00 and 08.00 . Distribution of 
participants according to their departments as follow: $20.8 \%$ of them work at the front desk, $54.5 \%$ are responsible for food services, $18.8 \%$ perform duty in accommodation services and $3 \%$ of the participants serve on administrative services.

Table 3: Relationship Between Systematic Soldiering and Organizational Commitment

\begin{tabular}{|c|c|c|c|c|c|c|}
\hline & & OCACort & OCCCort & OCNCort & OCort & SSort \\
\hline \multirow[t]{3}{*}{ OCACort } & Pearson Correlation & 1 & $-.285^{* *}$ & .185 & $.673^{* *}$ & $.427^{* *}$ \\
\hline & Sig. (2-tailed) & & .004 & .065 & .000 & .000 \\
\hline & $\mathrm{N}$ & 101 & 101 & 100 & 100 & 73 \\
\hline \multirow[t]{3}{*}{ OCCCort } & Pearson Correlation & $-.285^{* *}$ & 1 & -.082 & $.381^{* * *}$ & $-.308^{* *}$ \\
\hline & Sig. (2-tailed) & .004 & & .415 & .000 & .008 \\
\hline & $\mathrm{N}$ & 101 & 101 & 100 & 100 & 73 \\
\hline \multirow[t]{3}{*}{ OCNCort } & Pearson Correlation & .185 & -.082 & 1 & $.558^{* *}$ & .154 \\
\hline & Sig. (2-tailed) & .065 & .415 & & .000 & .196 \\
\hline & $\mathrm{N}$ & 100 & 100 & 100 & 100 & 72 \\
\hline \multirow[t]{3}{*}{ OCort } & Pearson Correlation & $.673^{* *}$ & $.381^{* *}$ & $.558^{* *}$ & 1 & .221 \\
\hline & Sig. (2-tailed) & .000 & .000 & .000 & & .062 \\
\hline & $\mathrm{N}$ & 100 & 100 & 100 & 100 & 72 \\
\hline \multirow[t]{3}{*}{ SSort } & Pearson Correlation & $.427^{* *}$ & $-.308^{* *}$ & .154 & .221 & 1 \\
\hline & Sig. (2-tailed) & .000 & .008 & .196 & .062 & \\
\hline & $\mathrm{N}$ & 73 & 73 & 72 & 72 & 73 \\
\hline
\end{tabular}

**Correlation is significant at the 0.01 level (2-tailed).

OCAC: Affective commitment, OCCC: Continuation commitment, OCNC: Normative commitment, SS: Systematic soldiering

In Table 3, results of Correlation analysis made to measure the relationship between systematic soldiering and organizational commitment are shown. According to the results, there is no relationship between variables of organizational commitment and systematic soldiering at $p<0,01$ significance level. A positive correlation $(\mathrm{r}=0.427)$ exists between systematic soldiering and affective commitment. On the other hand, an imperfect negative correlation $(\mathrm{r}=0.308)$ between systematic soldiering and continuation commitment is observed. Furthermore, there is no significant correlation between systematic soldiering and normative commitment. 
Table 4: Anova Test Results Showing The Relationship of The Service Area with Systematic Soldiering and Organizational Commitment

\begin{tabular}{|c|c|c|c|c|c|c|}
\hline & & $\begin{array}{l}\text { Sum of } \\
\text { Squares }\end{array}$ & $\mathrm{df}$ & $\begin{array}{c}\text { Mean } \\
\text { Square }\end{array}$ & $\mathrm{F}$ & Sig. \\
\hline OCACort & $\begin{array}{l}\text { Between } \\
\text { Groups } \\
\text { Within } \\
\text { Groups } \\
\text { Total }\end{array}$ & $\begin{array}{r}5.966 \\
67.687 \\
73.652\end{array}$ & $\begin{array}{r}5 \\
95 \\
100\end{array}$ & $\begin{array}{r}1.193 \\
.712\end{array}$ & 1.675 & .148 \\
\hline OCCCort & $\begin{array}{l}\text { Between } \\
\text { Groups } \\
\text { Within } \\
\text { Groups } \\
\text { Total }\end{array}$ & $\begin{array}{r}2.219 \\
47.476 \\
49.694\end{array}$ & $\begin{array}{r}5 \\
95 \\
100\end{array}$ & $\begin{array}{l}.444 \\
.500\end{array}$ & .888 & .492 \\
\hline OCNCort & $\begin{array}{l}\text { Between } \\
\text { Groups } \\
\text { Within } \\
\text { Groups } \\
\text { Total }\end{array}$ & $\begin{array}{r}.255 \\
27.959 \\
28.214\end{array}$ & $\begin{array}{r}5 \\
94 \\
99\end{array}$ & $\begin{array}{l}.051 \\
.297\end{array}$ & .172 & .973 \\
\hline OCort & $\begin{array}{l}\text { Between } \\
\text { Groups } \\
\text { Within } \\
\text { Groups } \\
\text { Total }\end{array}$ & $\begin{array}{r}1.463 \\
12.695 \\
14.158\end{array}$ & $\begin{array}{r}5 \\
94 \\
99\end{array}$ & $\begin{array}{l}.293 \\
.135\end{array}$ & 2.167 & .064 \\
\hline SSort & $\begin{array}{l}\text { Between } \\
\text { Groups } \\
\text { Within } \\
\text { Groups } \\
\text { Total }\end{array}$ & $\begin{array}{r}4.096 \\
19.777 \\
23.873\end{array}$ & $\begin{array}{l}67 \\
72\end{array}$ & $\begin{array}{l}.819 \\
.295\end{array}$ & 2.775 & .024 \\
\hline
\end{tabular}

In Table 4 Anova test results of the relationship of service area with systematic soldiering as well as organizational commitment are demonstrated. According to the results, those working in travel agency and as animators are the ones who have the lowest organizational commitment. Fields in which systematic soldiering is at the highest level are food and accommodation services. As shown in Kaplan and Çetinkaya's research, people working at floor services are the ones who are soldiering more as compared to the ones working at other departments (Kaplan and Çetinkaya, 2014: 32). 
Table 5: Anova Test Results Showing The Relationship of Hotel Type with Systematic Soldiering and Organizational Commitment

\begin{tabular}{|rl|r|r|r|r|r|}
\hline & Sum of Squares & df & Mean Square & F & \multicolumn{1}{c|}{ Sig. } \\
\hline OCCCort & Between Groups & 6.906 & 3 & 2.302 & 5.218 & .002 \\
& Within Groups & 42.789 & 97 & .441 & & \\
& Total & 49.694 & 100 & & & \\
\hline SSort & Between Groups & 9.736 & 2 & 4.868 & 24.105 & .000 \\
& Within Groups & 14.137 & 70 & .202 & & \\
Total & 23.873 & 72 & & & \\
\hline
\end{tabular}

In the Anova test results (Table 5), it is found out commitment of employees working at 2-star hotels are lower than the ones working at 3,4 and 5-star hotels. This situation is attributed to organizational culture, institutionalization of the businesses and regulations in working hours with respect to the increase in their stars. As the number of stars in the hotels increase, controls are done more often and this leads to decrease in systematic soldiering.

Table 6: Anova Test Results Showing The Relationship of Earning Level with Systematic Soldiering and Organizational Commitment

\begin{tabular}{|rl|r|r|r|r|r|}
\hline & Sum of Squares & df & Mean Square & F & Sig. \\
\hline OCCCort & Between Groups & 6.486 & 3 & 2.162 & 4.853 & .003 \\
& Within Groups & 43.209 & 97 & .445 & & \\
& Total & 49.694 & 100 & & & \\
\hline SSort & Between Groups & 5.035 & 3 & 1.678 & 6.148 & .001 \\
& Within Groups & 18.838 & 69 & .273 & & \\
Total & 23.873 & 72 & & & \\
\hline
\end{tabular}

Another result of Anova test (Table 6) is that workers whose earning is between 1500 and 2000 TL are more affiliated to their organizations and those who earn 2500-3000 TL are most likely to be soldiering. Although the normal expectation was employees feel more affiliated to their organization and they do not soldier as their wages increase, this was not the case in this study. The reason behind this is there are other variables affecting organizational commitment and systematic soldiering other than earning level. 
Table 7: Anova Test Results Showing The Relationship of Working Hours with Systematic Soldiering and Organizational Commitment

\begin{tabular}{|rl|r|r|r|r|r|}
\hline & Sum of Squares & df & Mean Square & F & Sig. \\
\hline OCACort & Between Groups & 5.728 & 2 & 2.864 & 4.132 & .019 \\
& Within Groups & 67.924 & 98 & .693 & & \\
& Total & 73.652 & 100 & & & \\
\hline SSort & Between Groups & 5.588 & 2 & 2.794 & 10.697 & .000 \\
& Within Groups & 18.284 & 70 & .261 & & \\
Total & 23.873 & 72 & & & \\
\hline
\end{tabular}

Anova test results (Table 7) state when workers work between 8.00 and 17.00 have the highest level of loyalty to the organization, while soldiering is common among the same group of people. In general, working hours are between 8.00 a.m. and 5 p.m. Workload is mostly between these mentioned hours and working hours besides them may not be too busy. Hence, it might be normal to have no need for soldiering.

\section{CONCLUSION}

In the current study, correlation, Anova and factor analysis model were used for measuring the relation between systematic soldiering and organizational commitment. In the results, in general there is no correlation between systematic soldiering and organizational commitment.

According to the research, systematic soldiering and affective commitment are positively correlated. In this case, as affective commitment increases, so does systematic soldiering. Moreover, there is positive but low correlation between systematic soldiering and normative commitment. The more affective commitment exists among workers, the more they are soldiering.

Anova tests put forth commitment is lower among those who are working at 2-star hotels as compared to the ones working at hotels with 3, 4 and 5 stars. Employees whose working hours are 8.00-17.00 fell more committed to their organizations. However, soldiering is common among the same people, at the same time. Participants whose wage is $1500-2000 \mathrm{TL}$ are more affiliated to their organization and those whose wage falls into the interval 2500-3000 TL are the ones who are most soldiering.

As seen in the tables, employees in the tourism sector are soldiering but it is neither significant nor systematic. At the same time there is no detected correlation between systematic soldiering and organizational commitment. 


\section{REFERENCES}

Akbolat, M., Işık, O. ve Karadağ, M. (2010). “Tıbbi Sekreterlerin Tükenmişlik ve Örgütsel Bağl1lık Tutumlarına İlişkin Bir Araştırma”, International Journal of Economic and Administrative Studies, 2(4), 41-64.

Akın, H. B. (2013). “Bilimsel Yönetimin İlkeleri”, Adres Yayınları, 6. Baskı, Ankara.

Alavi, S. Z., Mojtahedzadeh, H., Amin, F. and Savoji, A. P. (2013). "Relationship Between Emotional Intelligence and Organizational Commitment in Iran's Ramin Thermal Power Plant", ProcediaSocial and Behavioral Sciences, 84, 815-819.

Bahrami, M. A., Barati, O., Ghoroghchian, M. S., Montazer-alfaraj, R. and Ezzatabadi, M. R. (2015). "Role of Organizational Climate in Organizational Commitment: The Case of Teaching Hospitals", Osong Public Health and Research Perspectives, 1-5.

Balay, R. (2000). "Yönetici ve Öğretmenlerde Örgütsel Bağl1lık”, Nobel Yayın Dağıtım, Ankara.

Bayram, L. (2005). "Yönetimde Yeni Bir Paradigma: Örgütsel Bağl1lık”, Sayıştay Dergisi, 59, 125139.

Boylu, Y., Pelit, E. ve Güçer, E. (2007). “Akademisyenlerin Örgütsel Bağl1lık Düzeyleri Üzerine Bir Araştırma”, Finans Politik \& Ekonomik Yorumlar, 44(511), 55-73.

Casper, W. J., Harris, C., Taylor-Bianco, A. and Wayne, J. H. (2011). "Work-Family Conflict, Perceived Supervisor Support and Organizational Commitment Among Brazilian Professionals", Journal of Vocational Behavior, 79(3), 640-652.

Doğan, A., Bozkurt, S. ve Demir, R. (2012). "Sosyal Kaytarma Davranış1 ile Algılanan Görev Görünürlüğü Arasındaki İlişkinin İncelenmesine Yönelik Bir Araştırma”, SÜ İİBF Sosyal ve Ekonomik Araştırmalar Dergisi, 53-79

Durna, U. ve Eren, V. (2011). “Üç Bağl11ık Unsuru Ekseninde Örgütsel Bağl1lık”, Doğuş Üniversitesi Dergisi, 6(2), 210-219.

George, M. J. (1992). "Extrinsic And Intrinsic Origins of Perceived Social Loafing in Organizations", Academy of Management Journal, 35(1), 91-202.

Gürbüz, S. (2006). “Örgütsel Vatandaşlık Davranışı İle Duygusal Bağlılık Arasındaki İlişkilerin Belirlenmesine Yönelik Bir Araştırma”, AİBÜ-İIBF Ekonomik ve Sosyal Araştırmalar Dergisi, 3(1), 48-75.

Ilgın, B. (2013). “Toplumsal Bir Hastalık: Sosyal Kaytarma”, Uşak Üniversitesi Sosyal Bilimler Dergisi, 6(3), 238-270. 
Jung, H. S. and Yoon, H. H. (2016). "What Does Work Meaning to Hospitality Employees? The Effects of Meaningful Work on Employees' Organizational Commitment: The Mediating Role of Job Engagement”, International Journal of Hospitality Management, 53, 59-68.

Kanten, P. (2014). "İşyeri Nezaketsizliğinin Sosyal Kaytarma Davranışı ve İşten Ayrılma Niyeti Üzerindeki Etkisinde Duygusal Tükenmenin Aracılık Rolü”, Aksaray Üniversitesi İktisadi ve İdari Bilimler Fakültesi Dergisi, 6(1), 11-26.

Kaplan, M. ve Çetinkaya, A. Ş. (2014). "Sanal Kaytarma ve Demografik Özellikler Açısından Farklı1ıklar: Otel İşletmelerinde Bir Araştırma”, Anatolia: Turizm Araştırmaları Dergisi, 25(1), 26-34

Kaplan, M. ve Ögü̈t, A. (2012). “Algılanan Örgütsel Adalet İle Sanal Kaytarma Arasındaki İlişkinin Analizi: Hastane Çalışanları Örneği”, İşletme Fakültesi Dergisi, 13(1), 1-13.

Koc, E. (2000). "The Role and Potential of Marketing Communications in the Turkish Domestic Tourism Market", unpublished $\mathrm{PhD}$ thesis, Oxford Brookes University, Oxford

Koc, E. (2003). "The Role and Potential of Travel Agency Staff as a Marketing Communications Tool”, Tourism Analysis-An Interdisciplinary Journal, 8 (1), 105-111.

Koc, E. (2009). "A Review of Country Competitiveness, Tourism Industry Performance and Research Performance Relationships", Competitiveness Review, 19 (2), 119-133.

Koc, E. (2010). "Services and Conflict Management: Cultural and European Integration Perspectives", International Journal of Intercultural Relations, 34 (1), 88-96.

Koc, E., Yumusak, S., Ulukoy, M., Kilic, R. and Toptas, A. (2014). "Are Internship Programs encouraging or Discouraging? - A viewpoint of tourism and hospitality students in Turkey", Journal of Hospitality, Leisure, Sport \& Tourism Education, 15, 135-142

Latane, B., Williams, K.D. and Harkins, S. (1979). "Many Hands Make Light the Work: The Causes and Consequences of Social Loafing", Journal of Personality and Social Psychology, 37, 822832.

Luo, Z., Song, H., Marnburg, E. and Øgaard, T. (2014). “The Impact Of Relational Identity on The Relationship Between LMX, Interpersonal Justice, and Employees' Group Commitment”, International Journal of Hospitality Management, 41, 21-27.

Luo, Z., QU, H. and Marnburg E., (2013). "Justice Perceptions and Drives of Hotel Employee Social Loafing Behavior", International Journal of Hospitality Management, 33, 456-464.

Mahdi, O. R., Mohd, E. S. B. G. and Almsafir, M. K. (2014). "Empirical Study on the Impact of Leadership Behavior on Organizational Commitment in Plantation Companies in Malaysia”, Procedia-Social and Behavioral Sciences, 109, 1076-1087. 
Meyer, J. and Allen, N. (1991). “A Three-Component Model of Organizational Commitment”, Journal of Applied Psychology, 79, 15-23.

Morrow, P. C. (2011). "Managing Organizational Commitment: Insights from Longitudinal Research", Journal of Vocational Behavior, 79(1), 18-35.

Ng, T. W. and Feldman, D. C. (2011). "Affective Organizational Commitment and Citizenship Behavior: Linear and Non-Linear Moderating Effects of Organizational Tenure", Journal of Vocational Behavior, 79(2), 528-537.

Öğüt, A. ve Kaplan, M. (2011). “Otel İşletmelerinde Etiksel İklim Algılamaları ile Örgütsel Bağlıl1k Arasındaki İlişkinin Analizi: Kapadokya Örneği”, Dumlupınar üniversitesi Sosyal Bilimler Dergisi, 30, 191-206.

Özkalp, E., Aydın, U. ve Tekeli, S. (2012). "Sapkın Örgütsel Davranışlar ve Çalışma Yaşamında Yeni Bir Olgu: Sanal Kaytarma (Cyberloafing) ve İş İlişkilerine Etkileri”, Çimento Endüstrisi İşverenleri Sendikası, 18-33.

Permarupan, P. Y., Saufi, R. A., Kasim, R. S. R. and Balakrishnan, B. K. (2013). "The Impact of Organizational Climate on Employee's Work Passion and Organizational Commitment", Procedia-Social and Behavioral Sciences, 107, 88-95.

Shagholi, R., Zabihi, M. R., Atefi, M. and Moayedi, F. (2011). "The Consequences of Organizational Commitment in Education", Procedia-Social and Behavioral Sciences, 15, 246-250.

Stan, M. M. (2013). "Predictors of the Organizational Commitment in the Romanian Academic Environment", Procedia-Social and Behavioral Sciences, 78, 672-676.

Sultan, K., Bentahar, J., Wan, W. and Al-Saqqar, F. (2014). "Modeling and Verifying Probabilistic Multi-Agent Systems Using Knowledge and Social Commitments", Expert Systems with Applications, 41(14), 6291-6304.

Tengilimoğlu, D. ve Mansur, F. A. (2009). "İşletmelerde Uygulanan Mobbingin (Psikolojik Şiddet) Örgütsel Bağl1lı̆ga Etkisi”, International Journal of Economic and Administrative Studies, 1(3), 69-84.

Thompson, B. and Thornton B. (2007). "Exploring Mental-State Reasoning as a Social-Cognitive Mechanism for Social Loafing in Children", The Journal of Social Psychology, 147(2), 159174.

Yeh, Y. P. (2014). "Exploring the Impacts of Employee Advocacy on Job Satisfaction and Organizational Commitment: Case of Taiwanese Airlines", Journal of Air Transport Management, 36, 94-100. 
Yıng, X., Li, H., Jıang, S., Peng, F. and Lin, Z. (2014). “Group Laziness: The Effect of Social Loafing on Group Performance", Social Behaviour and Personality, 42(3), 465-472 